\title{
Information and Dialogue in the Struggle against Islamophobia: The Jeddah Declaration for a Culture of Moderation
}

\author{
Annalisa Pavan ${ }^{1, *}$ \\ ${ }^{1}$ Department of Philosophy, Sociology, Education and Applied Psychology, University of Padova, Italy \\ *Correspondence: Dipartimento FISPPA, Università degli Studi di Padova, via B. Pellegrino 28, 35137 Padova, Italy. \\ Tel: 39-049-827-1709 E-mail: annalisa.pavan@unipd.it
}

Received: February 28, 2017

Accepted: March 7, 2017 Online Published: March 15, 2017

doi:10.5430/wjss.v4n2p1

URL: https://doi.org/10.5430/wjss.v4n2p1

\begin{abstract}
The purpose of this paper is to introduce the Anti-Islamophobia Media Strategy presented during the 11th session of the Islamic Conference of Information Ministers (Session of the New Media to Counter Terrorism and Islamophobia), which took place in Jeddah, Kingdom of Saudi Arabia, 19-21 December 2016. Built around the idea of a culture of moderation, especially taking into consideration that moderation is "the pillar of Islamic identity", the Jeddah Declaration, issued at the end of the conference, represents the peaceful and determined commitment of the Muslim world to participate fully in the globalized world, building bridges and rejecting unfounded prejudice and generalizations. Considering that the proceedings of the Conference have gone largely unnoticed in Western media, this paper intends to bring them to the attention of the international academic community, and subsequently to offer comments and reflections that will also highlight the problematical relationship between knowledge and prejudice.
\end{abstract}

Keywords: Islamophobia, media strategy, organization of islamic cooperation, Saudi Arabia, western media

\section{Introduction}

The Organization of Islamic Cooperation (OIC) is the second largest inter-governmental organization after the United Nations. It was established in 1969 and consists of 57 Member States spread over four continents. It is the collective voice of the Muslim world, and committed to promoting international peace and harmony (OIC website, History of the Organization). In 1970, following the first meeting of the Islamic Conference of Foreign Ministers - a key body of the OIC - in Jeddah, Kingdom of Saudi Arabia, it was decided that Jeddah should also be home to the Permanent Secretariat of the OIC, which is the Organization's executive organ, and in time, several subsidiary organizations and affiliated institutions were created and headquartered in various Member States. The present Secretary General (Dr Yousef bin Ahmad Al Othaimeen) is Saudi Arabian, as was his predecessor (Iyad Ameen Madani).

Deeply concerned at the rising tide of Islamophobia in Western media, especially in the aftermath of 9/11, the OIC has been seeking since 2005 to counter this phenomenon with concrete measures. Several Summits were held, and Ministerial Resolutions issued, stressing the need not only to develop a comprehensive strategy aimed at combating Islamophobia on the one hand, but also the need to encourage coexistence and mutual understanding among different nations and different religions on the other. In particular, the Dushanbe Resolution (2010), the Astana Resolution (2011), but also the Libreville Resolution (2012), the Kuwait City Resolution (2015) among others; and, most importantly, the OIC 2025 Programme of Action approved in Istanbul in April 2016 — all these — while focusing on the interaction with external media (that is to say, the media in non-Muslim countries, mainly Western countries), paved the way for the final adoption of the OIC Media Strategy in Countering Islamophobia at the 11th session of the Islamic Conference of Information Ministers, held 19-21 December 2016 in Jeddah (Arab News, 20 December 2016 and 22 December 2016). This session will be referred to hereinafter as the Jeddah session, for short.

The proceedings of the Jeddah session, the "Session of the New Media to Counter Terrorism and Islamophobia", are collected in four papers available on the OIC website: "Resolutions adopted by the 11th Session of the Islamic Conference of Information Ministers" (referred to hereinafter as the Resolutions document); "OIC Media Strategy in 
Countering Islamophobia and its Implementation Mechanisms" (referred to hereinafter as the Islamophobia Media Strategy document); "Media Strategy of the Organization of Islamic Cooperation" (referred to hereinafter as the Media Strategy document); and "Report of the 11th Session of the Islamic Conference of Information Ministers Session of the New Media to Counter Terrorism and Islamophobia" (referred to hereinafter as the Report). The final communiqué of the Jeddah session, the Jeddah Declaration, was released on 21 December 2016, and this likewise can be viewed on the OIC website.

Considering that these proceedings and their most relevant contents - admittedly presenting a number of redundancies and including unnecessarily detailed lists — have gone largely unnoticed in Western media, this paper intends to bring them to the attention of the international academic community, and subsequently to offer comments and reflections that will also highlight the problematical relationship between knowledge and prejudice.

\section{Countering Islamophobia: The Strategy}

According to the Report, the Jeddah session discussed a number of media-related issues, progress on the launch of the OIC satellite channel, promoting media visibility for the OIC's lead role in cultural exchange, development and peace issues, and the empowerment of women in and through the media, to name just a few (pp.2-3). Among these issues, the Anti-Islamophobia Media Strategy, within the framework of the OIC 2025 Comprehensive Media Strategy, would seem to be especially timely and challenging. This study will therefore focus on the Anti-Islamophobia Media Strategy.

The essential pillars of the OIC Anti-Islamophobia Media Strategy are described in the Islamophobia Media Strategy document.

Although the term Islamophobia was first used in French and in English in the 1920s, it entered into common usage after the publication in 1997 of the report by the Runnymede Trust's Commission on British Muslims and Islamophobia entitled Islamophobia: A Challenge for Us All, where Islamophobia was defined as "an outlook or world-view involving an unfounded dread and dislike of Muslims, which results in practices of exclusion and discrimination". However, there is no widely accepted definition of Islamophobia among academics yet (see Cesari, 2006, Allen, 2010 and Bleich, 2011, among others).

In the words of the OIC Islamophobia Observatory, Islamophobia is "a contemporary form of racism and xenophobia motivated by unfounded fear, mistrust and hatred of Muslims and Islam...it is manifested through intolerance, discrimination, hostility and adverse public discourse.... Islamophobia is an affront to the human rights and dignity of Muslims" (Islamophobia Media Strategy document, p.1).

The opening remarks of the Jeddah session reveal serious and justified apprehension: "[The Ministers are] Concerned at the rising intolerance against Islam and Muslims in the West and in many areas in the world, both in the east and the west, exacerbated to a large extent by widespread reporting, writings, articles, interviews, commentaries, editorials, op-eds in some Western print and visual media, including social media, that has resulted in negative stereotyping and racial discrimination and victimization directed against Muslims and distortion of the Islamic faith, which is based on the core values of peace, tolerance, moderation and peaceful co-habitation with all other religions and beliefs". The OIC Information Ministers add that "[this] State of affairs poses a grave threat to global peace and security and endangers communal harmony, hindering the growth of a culture of mutual understanding and tolerance among diverse communities". It is recalled that the OIC "has consistently urged for debate with and within the Western media to show responsibility in combating prejudice against Islam and Muslim communities with a view to developing campaigns to foster respect for cultural and religious pluralism and diversity, while raising awareness of the positive contributions of Muslims, in order to promote tolerance and understanding" (Islamophobia Media Strategy document, pp.1-2, emphasis added). Hoping for "an international environment conducive to interfaith and intercivilization harmony" (p.1), as described by a past OIC resolution, the Jeddah session adopts the OIC Media Strategy in Countering Islamophobia. The strategy covers a short term, a medium term and a long term: indeed it is feared and expected that the correction of misperceptions and mistrust, and the building of dialogue and mutual knowledge, will take some considerable time.

The short term section comprises 10 points, of which the most challenging, one would suppose, are: "To enhance the presence of Muslims on the internet.....as the success of Islamophobes in the West is the failure of Muslims online. However, extra care should be considered while investing on this enhancement, as there is a need to be aware of unintended consequences of the increased presence of Muslims on the internet. In addition, there is a need to identify and support non-Muslim bloggers and researchers from outside the mainstream media positively disposed towards 
Islam and Muslims"; "To create, in cooperation with an experts committee consisting of scholars, legal experts, psychologists, sociologists and communication experts, powerful, appealing and strong content which is professionally and objectively prepared and unrelated to Islam. Muslims should be able to write or produce stories with media impact, however, having nothing to do with Islam" (Islamophobia Media Strategy document, points 3 and 4, p.2); "To develop Muslim's own narrative on daily issues. There should be stories giving the Islamic perspective on daily issues, such as environment, climate change, social justice, development, poverty, etc."; "To support publishing of books, memoirs, fictional materials, etc., by Muslims and non-Muslims. Preference may be given to presenting Islam as a religion with values and principles applicable on sciences and other issues of concern to the West, human rights, democracy and good governance" (Islamophobia Media Strategy document, points 5 and 10, p.3).

The medium term section comprises 10 points, of which points 4, 6 and 10, interestingly, focus on the broad educational picture: "To use success stories in the Muslim world as a means to show that the interests of Muslims are similar to the rest of the world when it comes to democracy, good governance and human rights"; "To promote, through media coverage, Muslim students' activities in Western countries' campuses"; "To establish academic fellowships at communication faculties of major world universities to study this phenomenon [i.e. Islamophobia] and means to combat it" (Islamophobia Media Strategy document, points 4, 6, 10, p.4).

Finally, the long term section comprises 7 points, including three that draw attention to the fundamental issue of correctness and responsibility as concerning the use of information: "To call media professionals to develop, articulate and implement voluntary codes of conduct to counter Islamophobia. The OIC and its Member States should be vocal in calling media professionals to use the power they have with responsibility through accurate reporting"; "To engage with Western governments in creating awareness against the dangers of Islamophobia by addressing the responsibility of media on the issue"; "To encourage training programs to help Muslim civil societies in the West to understand journalistic critical international issues - particularly in those fields where politics and religion intersect - and enhance their capacity to inform the public accurately and in a balanced way"; and education has another important role: "To encourage scholarship programs for Westerners to study in the Muslim world and disseminate this information throughout media outlets. The scholarships should focus on Islamic education, and it is advisable that the same subject is funded in Western universities"; (Islamophobia Media Strategy document, points 1, 3, 6, 4, pp.4-5). In a broader perspective, "Both short-term and long-term targets include seeding a proactive anti-Islamophobia grassroots media network in the United States and specific European countries, overseen by OIC...; researching and identifying the key misconceptions about Islam and Muslims, and refuting these through a comprehensive online resource supported with social media; building alliances with scholarly, journalistic and media communities, and civil societies" (p.6).

The OIC Anti-Islamophobia Media Strategy forms part of the Comprehensive Media Strategy, which in turn forms part of the OIC 2025 Programme of Action, where pertinent to the media, as reported in the Media Strategy document: "The OIC 2025 Programme of Action, approved at the 13th Islamic Summit - Istanbul, 14-15 April 2016 - emphasizes the importance of print and audio media, along with social networks, as effective and useful tools in information dissemination and public opinion shaping" (p.1), and in the Resolutions document, which also stresses that the Istanbul Summit "recognized the decisive role the media, including social media, can assume in projecting the bright image of Islam and Member States to the outside world and achieving the objectives if Islamic solidarity" (p.6, emphasis added). Within the Comprehensive Media Strategy, which includes multiple and diverse objectives (promoting trade and tourism exchange between OIC Member States, maintaining an enhanced presence and role for the OIC regionally and worldwide, presenting the true image of Islam to the world, increasing visibility for the OIC online and elevating its credibility and transparency, encouraging investment in human capital in the media sector in the Member States, to name just a few), the anti-Islamophobia objective - summarized in the document as "Counter anti-Islam and anti-Muslim propaganda spread by various Western media with the intent to fuel Islamophobia and distort the true image of Islam" (p.2), and discussed more fully in the Islamophobia Media Strategy document, as explained above in detail — is probably the most difficult, and the one most demanding of time and resources, and yet, it is strategically important and indeed inescapable.

\section{The Jeddah Declaration: Moderation and Objectivity}

The final communiqué of the Islamic Conference of Information Ministers, the Jeddah Declaration, was released on 21 December 2016.

Profoundly concerned at the growing threat posed by Islamophobia - exacerbated by terrorist acts, which in turn 
disseminate hate and discrimination against Muslims first and foremost, but also spread violence and hatred everywhere - the OIC Information Ministers acknowledge the pivotal role of the media, and the new media in particular, "as a platform for reporting, synergy and publication, and the establishment of bridges of communication and dialogue with the world". Recalling that "moderation is the pillar of Islamic identity", the Ministers call for "media synergy" based on the "moderate discourse" which lies at the very heart of the Islamic religion. Importantly, given the rapid changes impacting on the world in general, "and the Muslim world in particular", the media must act quickly to develop "messages based on diversity, plurality and on addressing the 'other' in a language suitable to his/her social reality". Consistent with this willingness to embrace cultural diversity, the Ministers "condemn all manifestations of violence, extremism, fanaticism and terrorism which distort the noble messages of human cultures" (Jeddah Declaration, p.1), and "reject categorically and denounce strongly the phenomenon of violence and terrorism", all the more when associated with "Islam, a religion of compassion and peace" (p.2).

Furthermore, the Ministers underline the urgent need for objectivity and professionalism in the fight against Islamophobia: "[The Jeddah session] calls for media in Member States to serve truth....and to demonstrate the greatest degree of professionalism and objectivity in reporting facts and addressing political, economic, social and cultural issues in full respect for the principles of plurality and diversity of opinion, and a continued approach to open up to modernity while sticking to the constants of the Ummah [the community of the Muslim believers] and persistent desire to exercise freedom widely with a high sense of responsibility" (p.2, emphasis added). Such an approach could be said to reflect the combination of aspiration and determination that is championed especially by Saudi Arabia, as explained elsewhere (Pavan, 2016, and Pavan, 2014, where the tension between global aspiration and local determination in Saudi Arabia is presented). The staunch defence of traditions, values and identity is not incompatible with globalization, and the media can be powerful and effective in circulating messages of peaceful coexistence in a world of diversity, and "to promote dialogue between the Islamic culture and the world's cultures" (p.2).

\section{Some Reflections}

Having outlined the main points of the Jeddah Declaration, it is argued here that the proceedings of the Jeddah session are thought-provoking on a variety of issues, and five points in particular are brought to the attention of the international academic community.

Firstly, an analysis of the proceedings confirms that there is indeed, self-evidently, an Islamophobia problem and, most importantly, that the problem is well understood by the OIC. The Organization provides a definition of the phenomenon and is fully aware of its tragic consequences, observing also that it is putting world peace at risk. Moreover, expressions such as "external media" and "the outside world" used with reference to non-Muslim countries, as well as to those countries where Muslims are a minority - in this regard, it is noteworthy that the Islamic Conference of Information Ministers is already familiar with such expressions: see for example the Rabat Declaration, issued by the 8th session of the Conference in January 2009, where it refers to "the outer world", cited in the Resolutions document, p.6 - may be a source of concern: do such expressions suggest a perceived division between nations, cultures and religions; or, more optimistically, do they indicate a healthy measure of divergence in a globalized world where it is increasingly difficult for a wide variety of identities to coexist?

Secondly, the Jeddah session did not enjoy extensive coverage in Western media; and, more in general, it seems that OIC activities are not sufficiently publicized and therefore not well known around the world. Perhaps the Organization should take more effective action to make its voice heard? It is possible that, for example, a more thorough and critical knowledge in Western countries of what the Jeddah session was about, could help dismantle widespread misunderstandings about the attitude of Muslims toward terrorist acts.

Thirdly, the OIC Information Ministers bring up the issue of quality as touching information, and rightly so: when quality and objectivity are neglected, they are replaced by misinformation and misconceptions, which in turn breed hate, prejudice, intolerance and war. As declared in the Preamble to the Constitution of UNESCO, "since wars begin in the minds of men, it is in the minds of men that the defenses of peace must be constructed. Ignorance of each other's ways and lives has been a common cause, throughout the history of mankind, of that suspicion and mistrust between the peoples of the world through which their differences have all too often broken into war. Peace must be founded, if it is not to fail, upon the intellectual and moral solidarity of mankind". In short, moderation, quality information and objectivity can be very effective tools for peace, tolerance and human development. So, the message issued by the Jeddah Declaration is one of high moral value. 
Fourthly, these proceedings reflect careful and in-depth knowledge, on the part of the OIC Member States and organs, of what the outside world is thinking, discussing, writing and saying about the issues under discussion, most notably Islamophobia, the media, terrorism, and objectivity in information. Such awareness and attention could be seen as a sign of commendable commitment to know more about "the other" and to start peaceful and constructive dialogue, with the aim of combatting prejudice through knowledge. So, the outside world should play its part as well, and respond with equal awareness and attention.

Last but definitely not least, although Islamophobia is essentially a negative phenomenon, as highlighted by the Jeddah Declaration, it could, paradoxically, turn into a unique opportunity for the Muslim community to offer clarifications about Islam "in a thoughtful and effective manner" and "to resume its contribution to the human civilization in a manner commensurate with its heritage" (pp.2-3). It is hoped that the Muslim nations are ready to take up this challenge.

\section{Conclusion}

This paper has introduced the Anti-Islamophobia Media Strategy presented during the 11th session of the Islamic Conference of Information Ministers of the Member States of the OIC (Session of the New Media to Counter Terrorism and Islamophobia), which took place in Jeddah on 19-21 December 2016. Built around the idea of a culture of moderation, especially taking into consideration that moderation is "the pillar of Islamic identity", the Jeddah Declaration, issued at the end of the conference, represents the peaceful and determined commitment of the Muslim world to participate fully in the globalized world, building bridges and rejecting unfounded prejudice and generalizations.

Moreover, the Jeddah Declaration firmly rejects any extremism, terrorism and fanaticism, and invites the Ummah "to regain its active presence in the march towards progress, development and prosperity" (p.3).

This paper encourages the Western academic community in particular, and the Western audience in general, to read the Jeddah session proceedings. This could be a new opportunity for academics, as well as the media, to re-evaluate their approach when considering "the other", the views and wishes of the Muslim world expressed through the Islamic Conference of Information Ministers in Jeddah in December 2016.

Finally, borrowing the Saudi Minister of Culture and Information dr Al Toraifi's words, this study strongly encourages the OIC Member States "to accomplish integrative cultural work among Arab countries [and Muslim countries more in general] to contribute to the promotion of thought and knowledge and to spread the spirit of peace and tolerance".

\section{References}

Allen, C. (2010). Islamophobia. Farnham: Ashgate Publishing Limited.

Arab News. (2016, December 16). Al-Toraifi: Promoting culture is Saudi government policy. Retrieved December 16, 2016 from http://www.arabnews.com/node/1025066/saudi-arabia

Arab News. (2016, December 20). OIC Information Ministers'conference opens. Retrieved December 20, 2016, from http://www.arabnews.com/node/1027021/saudi-arabia

Arab News. (2016, December 22). OIC Information Ministers map out strategy to combat terrorism. Retrieved December 22, 2016, from http://www.arabnews.com/node/1027956/saudi-arabia

Bleich, E. (2011). What is Islamophobia and How Much is There? Theorizing and Measuring an Emerging Comparative Concept. American Behavioral Scientist, 55(12), 1581-1600. http://dx.doi.org/10.1177/0002764211409387

Cesari, J. (2006). Introduction: Use of the term "Islamophobia" in European Societies. In J. Cesari (Ed.), Securitization and religious divides in Europe - Muslims in Western Europe after 9/11: Why the term Islamophobia is more a predicament than an explanation. Submission to the Changing Landscape of Citizenship and Security: 6th PCRD of the European Commission. (pp.5-48).

Organization of Islamic Cooperation. (2016). Jeddah Declaration. 11th Session of the Islamic Conference of Information Ministers of the Member States of the Organization of Islamic Cooperation. Jeddah, Kingdom of Saudi Arabia, 21 December 2016. OIC/ICIM-11/2016/DEC/FINAL. Retrieved January 28, 2017, from http://www.oic-oci.org/confdetail/?cID=4\&lan=en 
Organization of Islamic Cooperation. (2016). Media Strategy of the Organization of Islamic Cooperation. 11th Session of the Islamic Conference of Information Ministers - Session of the New Media to counter terrorism and Islamophobia. Jeddah, Kingdom of Saudi Arabia, 21 December 2016. OIC/ICIM-11/2016/INF/DMS. Retrieved January 28, 2017, from http://www.oic-oci.org/confdetail/?cID=4\&lan=en

Organization of Islamic Cooperation. (2016). OIC Media Strategy in Countering Islamophobia and its Implementation Mechanisms. 11th Session of the Islamic Conference of Information Ministers - Session of the New Media to counter terrorism and Islamophobia. Jeddah, Kingdom of Saudi Arabia, 21 December 2016. OIC/ICIM-11/2016/INF/DMS-ISLAMOPHOBIA. Retrieved January 28, 2017, from http://www.oic-oci.org/confdetail/?cID=4\&lan=en

Organization of Islamic Cooperation. (2016). Report of the 11th Session of the Islamic Conference of Information Ministers - Session of the New Media to counter terrorism and Islamophobia. Jeddah, Kingdom of Saudi Arabia, 21 December 2016. OIC/ICIM-11/2016/MIN-REP/FINAL. Retrieved January 28, 2017, from http://www.oic-oci.org/confdetail/?cID=4\&lan=en

Organization of Islamic Cooperation. (2016). Resolutions adopted by the 11th Session of the Islamic Conference of Information Ministers - Session of the New Media to counter terrorism and Islamophobia. Jeddah, Kingdom of Saudi Arabia, 21 December 2016. OIC/ICIM-11/2016/RES/FINAL. Retrieved January 28, 2017, from $\mathrm{http}: / / \mathrm{www}$.oic-oci.org/confdetail/?cID=4\&lan=en

Organization of Islamic Cooperation. (2017). History of the Organization. Retrieved February 8, 2017, from http://www.oic-oci.org/page/?p_id=52\&p_ref=26\&lan=en

Pavan, A. (2014). The New Saudi Educational Renaissance: In between the "Capacity to Aspire" and the "Capacity to Remember". Higher Education Studies, 4(5), 37-46. http://dx.doi.org/10.5539/hes.v4n5p37

Pavan, A. (2016). Higher Education in Saudi Arabia: Rooted in Heritage and Values, Aspiring to Progress. International Research in Higher Education, 1(1), 91-100. http://dx.doi.org/10.5430/irhe.v1n1p91

Runnymede Trust. (1997). Islamophobia: A Challenge for Us All. London: Runnymede Trust.

UNESCO. (1946). Constitution of the United Nations Educational, Scientific and Cultural Organization. Retrieved February 13, 2017 , from http://portal.unesco.org/en/ev.phpURL_ID=15244\&URL_DO=DO_TOPIC\&URL_SECTION=201.html 